\title{
A new species of Microglanis (Siluriformes: Pseudopimelodidae) from upper rio Paraná basin, Brazil
}

\author{
Oscar Akio Shibatta and Ricardo Cardoso Benine
}

\begin{abstract}
Microglanis garavelloi, new species, collected in tributaries of rio Paranapanema and rio Tietê, is the first species of the genus described from upper rio Paraná basin. The new species can be distinguished from other species of Microglanis on morphometric characters, color pattern, caudal-fin shape, pectoral-spine morphology and lateral line development. Characters used specifically to distinguish M. garavelloi from M. cottoides (laguna dos Patos and rio Uruguay basins) and M. parahybae (rio Paraíba do Sul basin) include morphometrics, color pattern and pectoral-spine serration.

Microglanis garavelloi, espécie nova, coletado em tributários do rio Paranapanema e rio Tietê, é a primeira espécie do gênero descrita da bacia do alto rio Paraná. A nova espécie pode ser distinguida das outras espécies de Microglanis com base em caracteres morfométricos, padrão de colorido, forma da nadadeira caudal, morfologia do espinho da nadadeira peitoral e desenvolvimento da linha lateral. Caracteres utilizados para distinguir M. garavelloi de $M$. cottoides (bacias da laguna dos Patos e rio Uruguai) e M. parahybae (bacia do rio Paraíba do Sul) incluem a morfometria, o padrão de colorido e as serras do espinho da nadadeira peitoral.
\end{abstract}

Key words: Bumble bee catfish, Freshwater fishes, Neotropical, rio Paranapanema, rio Tietê.

\section{Introduction}

Microglanis was proposed by Eigenmann (1912) as a monotypic genus to include the species Microglanis poecilus. The genus is easily distinguished from other Pseudopimelodidae by its small adult size (no greater than 11 $\mathrm{cm} \mathrm{SL}$ ), premaxillary tooth plate with rounded lateral margin and no posterior extension, and an incomplete lateral line (Eigenmann, 1912; Gomes, 1946; Mees, 1974).

The 13 species of Microglanis are distributed in the Orinoco and Amazon basins, one Pacific coast drainage in Ecuador, the Maracaibo basin (rio Catatumbo), lago Valencia and Caribbean drainages in Venezuela, Atlantic coastal drainages of the Guianas and eastern and southern Brazil from the rio São Francisco to the state of Rio Grande do Sul, and Uruguay basin (Mees, 1974; Shibatta, 2003; Bertaco \& Cardoso, 2005; Mori, 2005). Prior to this study, Microglanis had not been reported from the rio Paraná basin despite extensive collections from this region.

A recent collection in the rio Tibagi, in Paraná State, Brazil, revealed a population of a new species of Microglanis. Additional specimens were subsequently discovered in museums collected from the rio Tietê basin, São Paulo State, Brazil, in Promissão, Cosmópolis, and Botucatu municipalities. The specimens from the basins of Tibagi and Tietê rivers were found to represent a new species described herein as Microglanis garavelloi. A morphometric analysis was performed to distinguish M. garavelloi from M. parahybae and M. cottoides, distributed in the Paraíba do Sul and Uruguay basins respectively, because $M$. parahybae has a similar pattern of coloration and the new species was misidentified as M. cottoides by previous authors (e.g. Visotto et al., 1999).

\section{Material and Methods}

Measurements were taken point-to-point with digital caliper to $0.01 \mathrm{~mm}$, following Malabarba \& Mahler (1998), except for body depth, which was taken at the dorsal-fin origin. The new species, M. parahybae and M. cottoides were compared using size-free canonical variate analysis (SFCVA) in order to test hypothesized differences among the species and to identify diagnostic characters. The program SAS was used to calculate the SFCVA, according to the method developed by Reis et al. (1990). Meristic data include numbers of pectoralfin rays, pelvic-fin rays, dorsal-fin rays, caudal-fin rays, gill rakers, vertebrae, and branchiostegal rays. Counts of bilaterally symmetrical features were made on the left side of the body. Osteological characters were examined from specimens

Museu de Zoologia da Universidade Estadual de Londrina, Departamento de Biologia Animal e Vegetal, Universidade Estadual de Londrina, Centro de Ciências Biológicas, 86051-990Londrina, PR, Brazil.e-mail: shibatta@uel.br 
cleared and stained (cs) according to the procedure of Dingerkus \& Uhler (1977). Vertebral counts include only free centra, with the compound caudal centra (pleural $1+$ ural 1) counted as a single element. Institutional abbreviations are as in Leviton et al. (1985), with the addition of MZUEL (Museu de Zoologia da Universidade Estadual de Londrina), LBP (Laboratório de Biologia de Peixes da Universidade Estadual Paulista - campus de Botucatu), and LIRP (Laboratório de Ictiologia de Ribeirão Preto da Faculdade de Filosofia, Ciências e Letras de Ribeirão Preto - Universidade de São Paulo). Other abbreviations are SL, standard length and HL, head length.

\section{Key to species of Microglanis from southern Brazil:}

1. Squarish head in dorsal view (more pronounced in adults); mouth width $67-85 \% \mathrm{HL}$

M. eurystoma (upper rio Uruguai drainage)

1 '. Conical head in dorsal view; mouth width $50-72.4 \%$ HL ...2

2. Dark blotch beneath adipose fin not extending to anal fin as continuous bar ...................................... 3

2 '. Dark continuous bar on posterior flank from base of adipose fin to that of anal fin ............................. 4

3. Caudal-peduncle depth $9.8-11.4 \%$ of SL, pectoral-girdle width $25.6-29.7 \%$ of SL

M. parahybae (rio Paraíba do Sul drainage)

3 . Caudal-peduncle depth $10.8-16.8 \%$ of SL, pectoral-girdle width $28.2-33.9 \%$ of SL

M. garavelloi (upper Paraná drainage)

4. Dorsal and anal fins entirely dark brown .... M. nigripinnis (rio Macacu and rio São João drainage)

4 '. Dorsal and anal fins dark distally but with light areas near base

5. Maxillary barbel short, not reaching pectoral-fin origin, caudal fin almost entirely black with narrow vertical light band near base ............. M. malabarbai (rio Ijuí drainage)

5'. Maxillary barbel extending to pectoral-fin origin, caudal fin almost entirely black or light with large dark brown band in middle....

6. Body width $27-34 \%$ of SL, head length $29-34 \%$ of SL ....... M. cottoides (laguna dos Patos and rio Uruguai drainages)

$6^{\prime}$. Body width $22-29 \%$ of SL, head length $25-29 \%$ of SL M. cibelae (coastal drainages from northern Rio Grande do Sul and Santa Catarina states)

\section{Microglanis garavelloi, new species} Figs. 1,2

Holotype. MZUSP 88006 (formerly MZUEL 1730 in part), 31.72 mm SL; Brazil, Paraná, Jataizinho: ribeirão Taquari, 2312'24"S 5056'50"W, 20 Aug 1999, O. A. Shibatta et al.

Paratypes. Brazil, Paraná: MZUEL 1677, 10 (3 cs), 19.0-37.4 mm SL; same locality as holotype, 17 Oct 1998, O. A. Shibatta et al. MCP 38592 (formerly MZUEL 1678), 4, 24.1-27.6 mm SL, same locality as holotype, 1 Dec 1998, O. A. Shibatta et al. MZUEL, 1679, 1, $23.1 \mathrm{~mm}$ SL, tributary of ribeirão Taquari, Jataizinho, 1 Dec 1998, O. A. Shibatta et al. ANSP 181199 (formerly MZUEL 1729), 5, 20.8-27.5 mm SL, same locality as holotype, 28 Jul 1999, Equipe de Coleta de Peixes da UEL (ECPUEL). MZUSP 88007 (formerly MZUEL 1730), 4, 24.7$31.7 \mathrm{~mm}$ SL, collected with the holotype, 20 Aug 1999, ECPUEL. MZUEL 1731, 1, $22.7 \mathrm{~mm}$ SL, same locality as holotype. MZUEL 1732, 2, 23.4-30.7 mm SL, same locality as holotype, 5 Jan 2000, ECPUEL. São Paulo: MZUEL 3288, 6 (1 cs), 24.9$28.2 \mathrm{~mm}$ SL, Ribeirão Pau D’álho, tributary to reservatório de Canoas II; Ibirarema, 7 Feb 2001, S. G. Britto. MZUSP 39814, 1, $29.2 \mathrm{~mm}$ SL, rio Alambari, Botucatu, 6 Jan 1982, U. Caramaschi et al. MZUSP 39888, 3, 25.4-27.7 mm SL, rio Capivara, Botucatu, 6 Jan 1982, U. Caramaschi et al. MZUSP 39931, 2, 34.2-34.5 $\mathrm{mm}$ SL, rio do Peixe, Anhembi, 7 Jan 1982, U. Caramaschi et al. MNRJ 19198, 2, 26.4-30.8 mm SL, rio Lambari, Botucatu, 1 Dec 1983, U. Caramaschi, \& J. M. R. Aranha. LIRP 2245, 7, 18.933,7 mm SL, Barreiro stream, rio Tietê, Promissão, 4 Sep 1999, R. M. C. Castro et al.

Non-Type specimens. Brazil, São Paulo: MZUSP 47798, 5 (1 cs), 27.0-39.7 mm SL, rio Araquá, rio Tietê tributary, Botucatu. LBP 492, 6, 25.0-32.4 mm SL, rio Capivara (ponte de Botucatu), Botucatu. MZUEL 3725, $34.0 \mathrm{~mm}$ SL, rio Pirapitingui, Cosmópolis. MZUEL 3726, 3, 35.8-41.8 mm SL, rio Pirapitingui, rio Jaguari tributary, Cosmópolis.

Diagnosis. Microglanis garavelloi is distinguished by having paired fins and anal fin mottled or with thin faint bands (vs. heavy dark bands in M. ater, M. pellopterygius, and $M$. nigripinnis); trunk with dark-brown saddles (vs. mottled in M. variegatus); caudal fin emarginate (vs. rounded in $M$. zonatus); tip of pectoral spine as distinct bony point ( $v s$. tip of pectoral spine soft, not as distinct bony point, but implanted between two teeth, one straight, pointing outwards from anterior margin and the other curved, pointing backwards from posterior margin in M. secundus (sensu Mees, 1974)); continuous portion of lateral line not reaching vertical through adipose-fin origin ( $v s$. reaching vertical through adipose-fin origin in $M$. iheringi); caudal peduncle with faint to dark blotch irregularly shaped (vs. triangular in M. poecilus); caudal-peduncle depth $10.8-17.0 \%$ of SL ( vs. 8.8-10.3\% of SL in M. eurystoma); trunk short relative to head (vs. long in $M$. cibelae); caudal fin lightly mottled with narrow vertical black band across central portions of fin rays and dark blotch beneath adipose fin not extending to anal fin as continuous bar ( $v s$. caudal fin almost completely black with narrow vertical white band across central portions of fin rays and dark continuous bar on posterior flank from base of adipose fin to that of anal fin in M. malabarbai); caudal-peduncle depth 10.8$16.8 \%$ of SL and pectoral-girdle width $28.2-33.9 \%$ of SL ( $v s$. caudal-peduncle depth $9.8-11.4 \%$ of SL and pectoral-girdle width $25.6-29.7 \%$ of SL in M. parahybae); dark blotch beneath adipose fin not extending to anal fin as continuous bar ( $v s$. dark continuous bar on posterior flank from base of adipose fin to that of anal fin in M. cottoides).

Description. Morphometric data are presented in Table 1. Head and anterior body depressed, body becoming laterally 


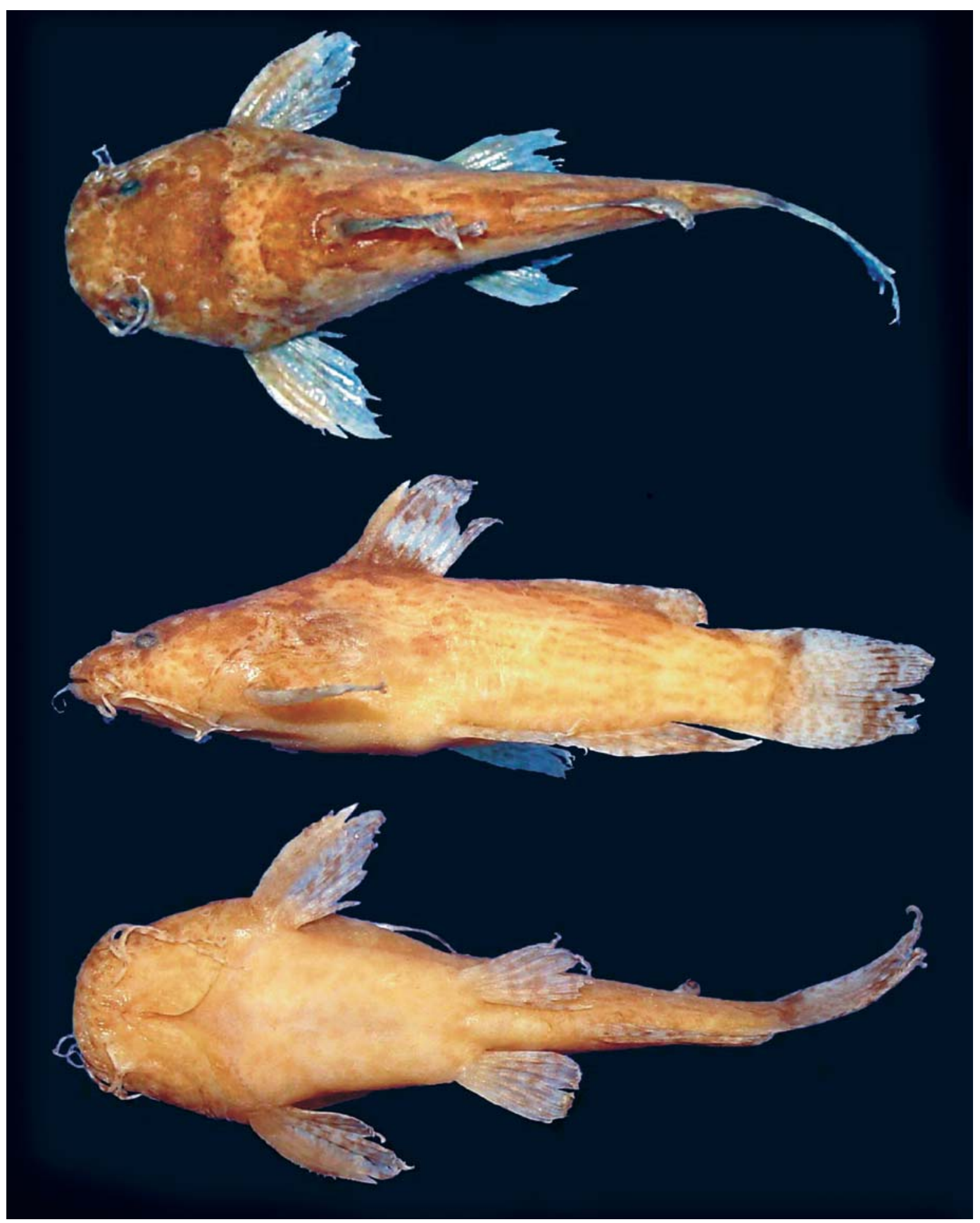

Fig. 1. Microglanis garavelloi, holotype, MZUSP 88006, $31.72 \mathrm{~mm}$ SL, ribeirão Taquari, rio Tibagi basin, Paraná, Brazil.

compressed posteriorly. Greatest body depth at dorsal-fin origin, greatest body width at pectoral-fin base. Cross-section at dorsal-fin origin approximately triangular. Head broader than long, rounded or conical (large specimens) in dorsal view. Snout short; anterior nostril tubular, proximate to upper lip; posterior nostril with flap, proximate to eye. Mouth wide and terminal. Teeth small and villiform. Premaxillary tooth patch rounded laterally, not forming posteriorly projecting angle. Dentary tooth patch crescent shaped, longer than premaxillary tooth patch. Barbels thin, flattened in cross section. One pair of maxillary and two pairs of mental barbels present. Maxillary barbel and outer mental barbel reaching base of pectoral fin. Eye small, superior, positioned in anterior half of head. Eye entirely covered by skin, without free orbital rim. Frontal fontanel large, oval, situated between eyes. Supraoccipital fontanel small, located in front of occipital process. 
Occipital process short and contacting predorsal nuchal plate. Lateral line incomplete, with 6 to 10 pores, followed by isolated neuromasts as far posteriorly as vertical through beginning of adipose fin. Preopercular-mandibular branch of cephalic sensory canal system with 10 pores; four anteriormost pores associated with lower lip. Infraorbital and supraorbital branches of cephalic canal system bearing 4 and 5 pores respectively. Gill membranes free, supported by 8 branchiostegal rays (counted in 1 cleared and stained specimen). Gill rakers villiform; gill rakers on first arch 1-3 upper + 4-6 lower $(n=22$ specimens). Dorsal fin rounded, with spinelet, strong spine, and 6 soft rays. Dorsal-fin spine smooth along anterior and posterior margins, shorter than dorsal-fin rays. Elongate adipose fin with base longer than that of anal fin; adipose fin free posteriorly. Caudal fin emarginate, upper lobe slightly longer than lower, tips of caudal lobes rounded. Principal caudal-fin rays 14 . Anal fin short and rounded, not confluent posteriorly with caudal fin. Anal-fin rays 9-11. Pectoral fin triangular. Tip of depressed pectoral fin does not reach base of pelvic-fin. Pectoral fin with strong spine and 5 soft rays. Anterior margin of spine with retrorse hooks proximally followed by antrorse hooks distally. Posterior margin of spine with strong retrorse hooks along entire length of spine, longer than those on anterior margin. Post-cleithral process slender and pointed. Pelvic fin rounded, with 6 soft rays. Tip of depressed pelvic fin not reaching anal-fin origin. Vertebrae 28 (2), $29(2), 30(1)$.

Color in alcohol. Ground color light brown alternating with slighty darker brown saddles on head and trunk. Darker area mottled with small light patches covering area on head from tip

Table 1. Morphometric data of Microglanis garavelloi from Upper rio Paraná basin. Standard length (SL) in mm, body proportions as ratios of SL or head length (HL). SD = standard deviation.

\begin{tabular}{lccc}
\hline & & \multicolumn{2}{c}{ Paratypes } \\
\cline { 2 - 4 } & Holotype & Low-high & Mean \pm SD \\
\hline Standard length (mm) & 31.72 & $20.8-41.8$ & $27.4 \pm 4.8$ \\
& Percents of HL & & \\
Eye diameter & 9.6 & $9.2-16.2$ & $12.6 \pm 1.9$ \\
Interorbital width & 51.8 & $42.5-55.7$ & $48.6 \pm 3.3$ \\
Head depth & 41.6 & $36.8-54.9$ & $43.7 \pm 4.6$ \\
Snout length & 39.4 & $37.4-45.2$ & $41.4 \pm 2.1$ \\
Mouth width & 60.7 & $56.2-72.4$ & $65.2 \pm 4.0$ \\
& 29.2 & $25.2-30.2$ & $28.0 \pm 1.2$ \\
Head length & 39.4 & $34.6-43.0$ & $39.3 \pm 1.6$ \\
Predorsal length & 15.2 & $9.8-17.1$ & $14.4 \pm 1.2$ \\
Dorsal-fin base length & 53.2 & $48.3-58.3$ & $51.7 \pm 2.0$ \\
Prepelvic length & 19.1 & $15.2-22.8$ & $19.6 \pm 1.7$ \\
Pelvic-anal fin distance & 26.6 & $19.2-33.1$ & $23.5 \pm 2.6$ \\
Body depth & 13.4 & $10.8-16.8$ & $12.6 \pm 1.1$ \\
Caudal-peduncle depth & 32.8 & $28.2-33.9$ & $30.4 \pm 1.1$ \\
Pectoral-girdle width & 28.4 & $24.0-40.4$ & $32.0 \pm 3.7$ \\
Maxillary-barbel length & 21.1 & $15.2-22.7$ & $20.5 \pm 1.5$ \\
Pelvic-fin length & 15.1 & $11.6-21.3$ & $14.8 \pm 1.9$ \\
Anal-fin base length & 23.0 & $18.5-26.2$ & $22.1 \pm 1.5$ \\
Pectoral-fin spine length & 16.7 & $11.3-19.0$ & $15.5 \pm 1.8$ \\
Dorsal-fin spine length & 21.8 & $11.4-22.2$ & $18.8 \pm 2.0$ \\
Body depth at adipose-fin origin & 24.4 & $14.3-27.4$ & $20.5 \pm 2.8$ \\
Adipose-fin base length & & & \\
\hline
\end{tabular}

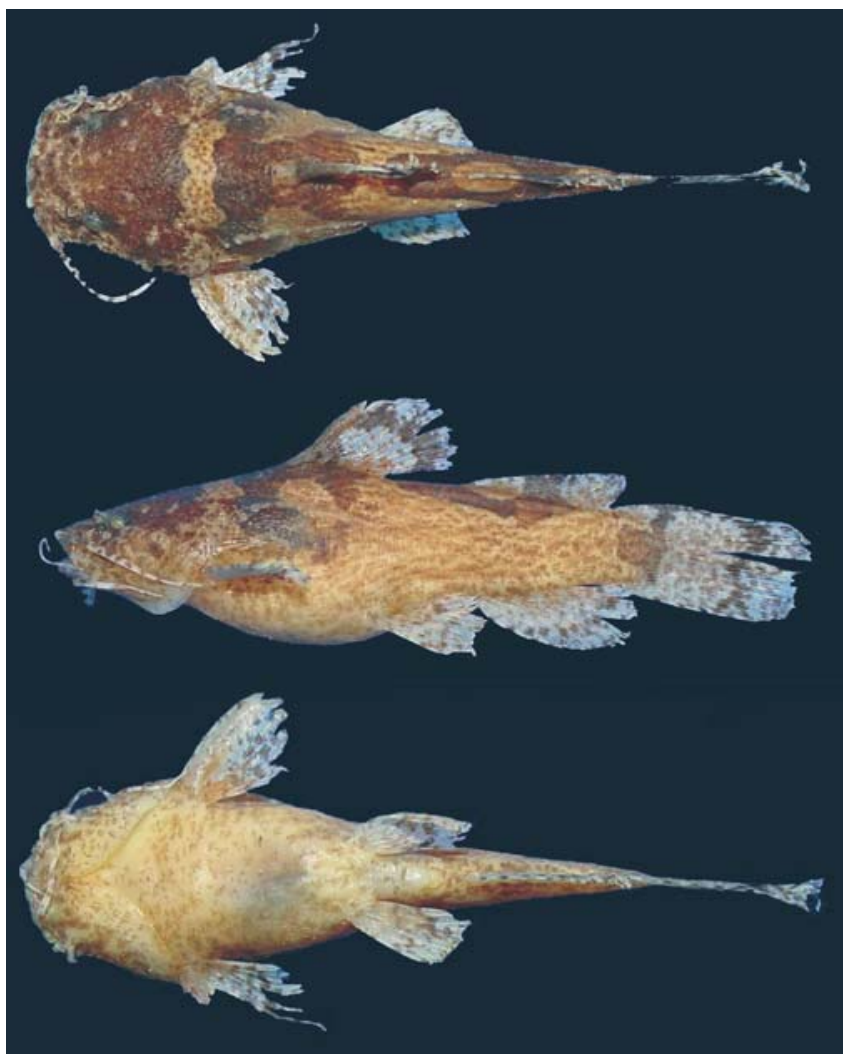

Fig. 2. Microglanis garavelloi, paratype, MZUEL 3288, 28.2 mm SL, ribeirão Pau D'alho, São Paulo, Brazil.

of snout to occipital region and extending ventrally onto interopercle and opercle. Large dark brown saddle located dorsally from nuchal region to posterior base of dorsal fin, center of saddle interrupted by small light brown patch over spinelet; saddle $n$-shaped in lateral view. Dark coloration on head and first dark saddle on body separated by lighter yoke-like marking across nuchal region. Second dark brown saddle extends from slightly posterior of dorsal fin to middle of adipose fin, center of saddle interrupted by large light brown oval patch over anterior third of adipose fin; dark saddle broadly v-shaped in lateral view. Irregular light brown vermiculations on sides along trunk. Dark brown band at base of caudal fin. Conspicuous dark brown band in middle of caudal fin. Dorsal fin with dark brown band across middle and another dark band along base. All fins and belly mottled with small dark brown spots.

Karyotype. A diploid number (2n) of 54 chromosomes, with 22 metacentric, 20 submetacentric and 12 subtelocentric chromosomes was reported for M. garavelloi (Vissotto et al.,1999), but identified therein as M. cottoides.

Ecological notes. In ribeirão Taquari, M. garavelloi was found in the marginal vegetation. Water velocity at that site was $0.05 \mathrm{~m} / \mathrm{s}$, mean depth of water $0.65 \mathrm{~m}$, stream width $3.71 \mathrm{~m}$, water transparency $0.19 \mathrm{~m}$, dissolved oxygen $7.15 \mathrm{mg} / \mathrm{L}, \mathrm{pH}$ 7.5 , temperature $23.2^{\circ} \mathrm{C}$, conductivity $211.8 \mathrm{mS} / \mathrm{cm}$ and alkalinity $110.63 \mathrm{mg} / \mathrm{L}$. 


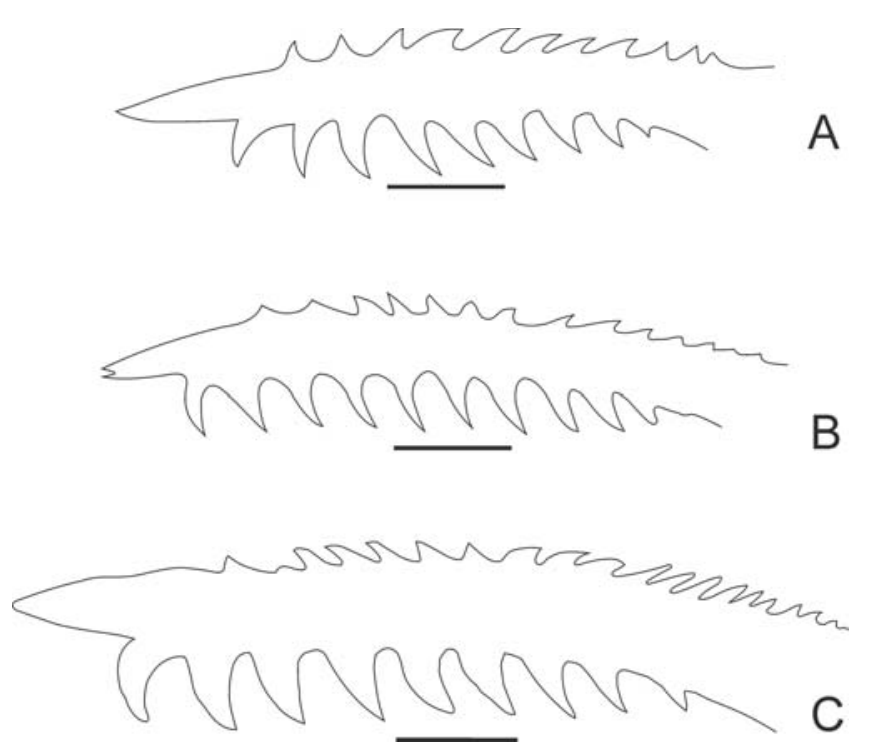

Fig. 3. Left pectoral spine of (A) Microglanis garavelloi (MZUEL 1677), (B) M. parahybae_(MNRJ 15989) and (C) $M$. cottoides $(\mathrm{MCP} 10826)$. Scale bar $=1 \mathrm{~mm}$.

Despite repeated collecting efforts in the rio Paraná basin in recent years, few specimens of $M$. garavelloi have been found, indicating that this might be a rare species (total $=65$ individuals, mean $=3.8$ per collection event).

Distribution. This species is known only from Brazil in the rio Paranapanema and rio Tietê basins (Fig. 4). In rio Paranapanema basin, M. garavelloi was collected in ribeirão Taquari, in Paraná State, and ribeirão Pau D'alho, tributary of rio Capivara, in São Paulo State. In the rio Tietê basin, it was collected in rio Pirapitingui, and Barreiro stream.

Etymology. The specific name, garavelloi, is homage to the Brazilian ichthyologist Julio Cesar Garavello.

Results and Discussion. Microglanis garavelloi can be discriminated from $M$. parahybae and $M$. cottoides in the first canonical variate axis that explains $64.7 \%$ of the variance (Fig. 5 and Table 2). Microglanis garavelloi has a caudal-peduncle depth, pectoral-girdle width, interorbital width, head depth, and pelvic-fin length greater than that found in $M$. parahybae and $M$. cottoides (higher positive values of CVI, $p=0.0001$ ). Microglanis cottoides and $M$. parahybae also have a pelvicfin to anal-fin distance and eye diameter greater than $M$. garavelloi (higher negative values of CVI, $p=0.0001$ ). In the analysis $M$. cottoides could be discriminated from the two other species by the second canonical axis, based on larger adipose-fin base length, eye diameter and pelvic-fin to analfin distance (higher positive value of CVII, $p=0,0013$ ). It is noteworthy that there is some geographic correlation between morphometric variation and river system within species $M$. garavelloi and $M$. parahybae.

The results of our analysis corroborate the work of

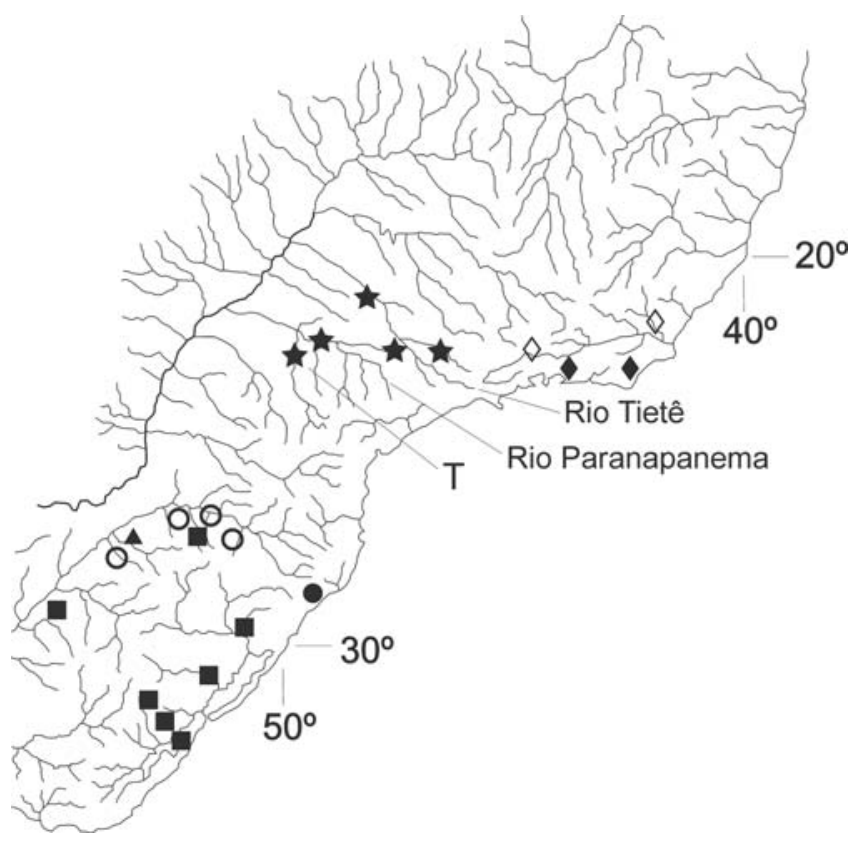

Fig. 4. Partial map of South America showing geographic distribution of southern species of Microglanis. M. cibelae (black circle); M. cottoides (black squares); M. eurystoma (open circles); M. garavelloi (black stars, T = type locality); M. malabarbai (black triangle); M. nigripinnis (black diamont); $M$. parahybae (open diamont). Each symbol may represent more than one locality or lot (Localities of $M$. cibelae, M. cottoides, and M. eurystoma after Malabarba \& Mahler, 1998; M. malabarbai after Bertaco \& Cardoso, 2005; M. nigripinnis after Bizerril \& Perez-Neto, 1992 and examined material; other species by examined material).

Malabarba \& Mahler (1998) who considered the species $M$. cottoides and $M$. parahybae to be valid. Previously, Gomes (1946) applied the name $M$. cottoides to all populations of Microglanis of southern Brazil whereas Mees (1974) considered M. cottoides to be a junior synonym of M. parahybae. We note that the pectoral spine illustrated by Mees (1974, Fig. 40a) for M. parahybae is more similar to spines in specimens identified here as M. cottoides (Fig. 3). However, we agree with Mees (1974), that the form of the spine changes with ontogenetic development, exhibiting a gradual increase of the number of serrations with an increase in spine length. To minimize such changes, we compared specimens with pectoral spines similar in length. As shown in figure 3 the pectoral-spine serrations in $M$. garavelloi are more robust and less numerous than in $M$. parahybae and $M$. cottoides for similarly sized specimens.

The species of Microglanis in southern Brazil exhibit subtle differences in color pattern that can be useful for identification mainly because intra-populational polymorphism was not observed. The color pattern of $M$. garavelloi is very similar to that of $M$. parahybae (both present vermiculations, and a dark saddle in the adipose fin area that does not extend to the anal fin). These two species are best differentiated on the 
Table 2. Loadings of variables in the first and second sizefree Canonical Variates of Microglanis garavelloi (rio Pirapitingui, rio Capibara, and rio Taquari), M. parahybae (rio Dois Rios, and rio Muriaé), and M. cottoides (Sanga das Águas Frias).

\begin{tabular}{lrlrl}
\hline & CV I & prob. & CVII & prob. \\
\hline Standard length & -0.77 & 0.0001 & -0.09 & 0.4388 \\
Eye diameter & -0.48 & 0.0001 & 0.38 & 0.0011 \\
Interorbital width & 0.35 & 0.0025 & 0.12 & 0.3048 \\
Head depth & 0.36 & 0.0022 & 0.08 & 0.5014 \\
Snout length & 0.06 & 0.6240 & 0.07 & 0.5404 \\
Mouth width & -0.09 & 0.4701 & 0.20 & 0.0878 \\
Head length & 0.02 & 0.8396 & 0.31 & 0.0090 \\
Predorsal length & -0.12 & 0.3065 & 0.16 & 0.1918 \\
Dorsal-fin base length & 0.16 & 0.1858 & 0.29 & 0.1320 \\
Prepelvic length & -0.23 & 0.0576 & -0.09 & 0.4701 \\
Pelvic fin to anal fin distance & -0.57 & 0.0001 & 0.37 & 0.0013 \\
Body depth & 0.32 & 0.0069 & -0.34 & 0.0043 \\
Caudal-peduncle depth & 0.63 & 0.0001 & 0.03 & 0.8236 \\
Pectoral-girdle width & 0.52 & 0.0001 & 0.27 & 0.0243 \\
Maxillary-barbel length & 0.09 & 0.4717 & -0.09 & 0.4641 \\
Pelvic-fin length & 0.37 & 0.0017 & 0.02 & 0.8737 \\
Anal-fin base length & -0.29 & 0.0129 & 0.05 & 0.6761 \\
Pectoral-fin spine length & -0.06 & 0.6249 & 0.01 & 0.9039 \\
Dorsal-fin spine length & -0.23 & 0.0551 & -0.31 & 0.0092 \\
Body depth at adipose-fin origin & 0.26 & 0.0263 & -0.24 & 0.0481 \\
Adipose-fin base length & -0.16 & 0.1740 & 0.42 & 0.0003 \\
\hline
\end{tabular}

basis of caudal-peduncle depth (10.8-16.8\% of SL in $M$. garavelloi vs. 9.8-11.4\% in M. parahybae) and pectoral-girdle width (28.2-33.9\% of SL in M. garavelloi vs. $25.6-29.7 \%$ in $M$. parahybae).

The identification of a new species endemic to the upper rio Paraná basin agrees with the hypothesis of Vari (1992), who considered this region to be an area of endemism. Other recently described species apparently endemic to the basin, such as Neoplecostomus paranensis Langeani, 1990 and Corumbataia cuestae Britski, 1997, reinforce this hypothesis. All of these species are characterized by their small size (less than $20 \mathrm{~cm} \mathrm{SL}$ ) and their occurrence in small streams. Nevertheless, it is possible that the apparently restricted distribution of M. garavelloi in the rio Tietê and rio Paranapanema basins may be the result of a lack of collecting efforts in small-river habitats of the upper rio Paraná basin. The occurrence of M. garavelloi at different sites in the upper rio Paraná suggests that the distribution of the genus in the ParaguayParaná basin may be broader than is presently known and tied to patchily distributed habitats. The utilization of more encompassing collecting techniques in a greater variety of habitats often reveals the presence of new species (Castro \& Casatti, 1997). Castro \& Menezes (1997) proposed that new species would be found with an increase of collections in upper rio Paraná basin.

Comparative material. Microglanis ater: ZMB 20932, $66.0 \mathrm{~mm}$ SL, Mittelbrazil. Microglanis cibelae: Brazil: Santa Catarina: MCP 14686, 5: 35.84 - 66.92 mm SL, rio Canoas. Microglanis cottoides: Brazil: Rio Grande do Sul: MCP 10826, 5 of 9: 39.22-52.41 mm SL, Sanga das Águas Frias, near Uruguay River. Microglanis eurystoma: Brazil: Rio Grande do Sul: Paratypes: MCP 12698, 12: 26.78-40.86 $\mathrm{mm}$ SL, arroio do Passo Alto. Microglanis iheringi: Venezuela: near

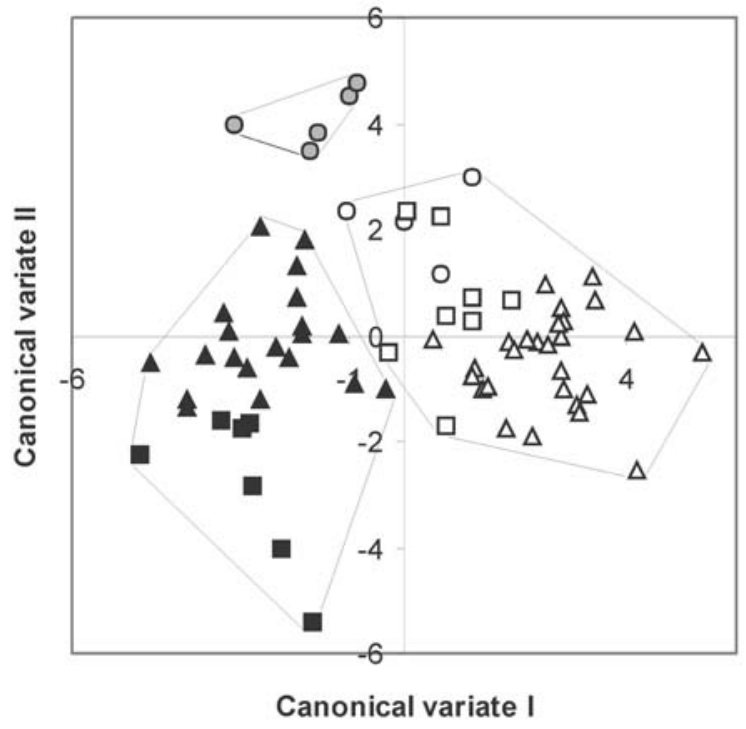

Fig. 5. Scatter diagram of scores of specimens on first and second axis of size-free Canonical Variate Analysis of Microglanis garavelloi from rio Pirapitingui (open circles), rio Capivara (open squares), rio Taquari (open triangles), $M$. parahybae from rio Dois Rios (solid triangles) and rio Muriaé (solid squares), and M. cottoides from Sanga das Águas Frias (solid circles).

Turmero: Paratype: USNM 121985, 30.0 mm SL, R. Turmero; Portuguesa: CAS 64403, 9 of 24: 23.41-39.56 mm SL, cano Marac en el puente $60 \mathrm{~km}$ via Guanare-Guanarito Rd. Microglanis nigripinnis: Brazil: Rio de Janeiro: MZUSP 80223, 1: 45.27 mm SL, rio São João tributary; MZUSP 80229, 2: 47.14-38.70 mm SL, rio São João tributary. Microglanis parahybae: Brazil: Rio de Janeiro: MNRJ 15989, 7 (5+2 cs): 27.58-34.87 mm SL, rio Dois Rios; MNRJ 16047, 5: 29.22 38.66 mm SL, rio Muriaé. Microglanis poecilus: Guyana: Paratypes: CAS 63679, 2: 24.11-25.37 mm SL, below Packeoo Falls, Essequibo River. Microglanis secundus: Brazil: Pará: INPA 5730, 7 of 30: 30.42$17.92 \mathrm{~mm}$ SL, rio Trombetas; INPA 7950, 6 of 11: 26.25-17.10 mm SL, rio Trombetas. Microglanis variegatus: Ecuador: Vinces: Holotype: CAS 17971, 45 mm SL; Paratype: CAS 63688, 2: 28.56-36.79 mm SL. Microglanis zonatus: Peru: Holotype: CAS 17970, 19.94 $\mathrm{mm}$ SL, R. Morona.

\section{Acknowledgments}

We are very grateful to R. P. Vari and M. Sabaj for a critical review; to J. L. de Figueiredo, O. T. Oyakawa for loans and assistance at MZUSP, and to P. Bartsch, P. Buckup, R. M. C. Castro, C. Ferraris, J. C. Garavello, S. L. Jewett, L. R. Malabarba, C. de Oliveira, R. P. Vari and J. Zuanon for loans of specimens. S. G. Britto donated the rio Pau d'álho specimens. M. C. C. de Pinna, M. L. Orsi, A. Souza, and E. S. Silva helped in collecting efforts. This study was partially supported by Financiadora de Estudos e Projetos (FINEP grant $N^{\circ} 1832$ / 95), Conselho Nacional de Pesquisa (CNPq/RHAE grant $\mathrm{N}^{\circ}$ 610148/96-6), the State of São Paulo Research Foundation (FAPESP grant No 98/05072-8), PRONEX (FINEP/CNPq grant $\left.\mathrm{N}^{\circ} 661058 / 1997-2\right)$ and the All Catfish Species Inventory (NSF DEB-0315963) 


\section{Literature Cited}

Bertaco, V. A. \& A. R. Cardoso. 2005. A new species of Microglanis (Siluriformes: Pseudopimelodidae) from the rio Uruguai drainage, Brazil. Neotropical Ichthyology, 3(1): 61-67.

Castro, R. M. \& L. Casatti. 1997. The fish fauna from a small forest stream of the upper Paraná River basin, southeastern Brazil. Ichthyological Exploration of Freshwaters, 7: 337-352.

Castro, R. M. \& N. A. Menezes. 1997. Estudo diagnóstico da diversidade de peixes do Estado de São Paulo. Pp.3-13 In: Castro, R. M. C. (Ed.), Biodiversidade do Estado de São Paulo, Brasil. Fapesp, São Paulo. 71p.

Dingerkus, G. \& L. D. Uhler. 1977. Enzyme clearing of Alcian Blue stained whole small vertebrates for demonstration of cartilage. Stain Technology, 52: 229-232.

Eigenmann, C. H. 1912. The freshwater fishes of British Guiana, including a study of the ecological grouping of species and the relation of the fauna of the plateau to that of the lowlands. Memoirs of the Carnegie Museum, 5(1): i-xxii, 1578, pls. 1-103.

Gomes, A. L. 1946. A review of Microglanis, a genus of South American catfishes, with notes on related genera. Occasional Papers of the Museum of Zoology, 494:1-19.

Leviton, A. E., R. H. Gibbs Jr., E. Heal \& C. E. Dawson. 1985. Standards in Herpetology and Ichthyology. Part 1. Standard symbolic codes for institutional resource collections in Herpetology and Ichthyology. Copeia, 1985: 802-832.
Malabarba, L. R. \& J. K. F. Mahler Jr. 1998. Review of the genus Microglanis in the rio Uruguay and coastal drainages of southern Brazil (Ostariophysi: Pimelodidae). Ichthyological Exploration of Freshwaters, 9(3): 243-254.

Mees, G. F. 1974. The Auchenipteridae and Pimelodidae of Suriname (Pisces, Nemathognathi). Zoologische Verhandelingen, 132: 1-256.

Mori, H. 2005. Três novas espécies de Microglanis Eigenmann, 1912 (Ostariophysi: Pseudopimelodidae) da bacia do Leste e da bacia do rio São Francisco, com comentários sobre a distribuição do gênero em drenagens costeiras. Unpublished MSc. Thesis, Universidade Estadual de Londrina, Londrina. 62p.

Reis, S. F., L. M. Pessôa \& R. E. Strauss. 1990. Application of size-free canonical discriminant analysis to studies of geographic differentiation. Revista Brasileira de Genética, 13: 509-520.

Shibatta, O. A. 2003. Family Pseudopimelodidae. Pp. 401-405 In: R. E. Reis, S. O. Kullander \& C. J. Ferraris Jr (Eds.). Check List of the Freshwater Fishes of South and Central America. Edipucrs, Porto Alegre. 729p.

Vari, R. P. 1992. Systematics of the Neotropical Characiform genus Cyphocharax Fowler (Pisces: Ostariophysi). Smithsonian Contributions to Zoology, 529: 1-137.

Vissotto, P. C., F. Foresti \& C. Oliveira. 1999. Karyotype description of five species of Pimelodidae (Teleostei, Siluriformes). Chromosome Science, 3: 1-7.

Received August 2005 Accepted October 2005 